\title{
Investigation of Relationship Between Peer Bullying and Cyberbullying Among Middle School Students ${ }^{1}$
}

\author{
Dr. Metin KOCATÜRK* \\ İstanbul Üniversitesi-Cerrahpaşa, Hasan Âli Yücel Eğitim Fakültesi, Eğitim Bilimleri Bölümü, \\ İstanbul / Türkiye, metin.kocaturk@iuc.edu.tr, ORCID: 0000-0002-2065-0022 \\ Prof. Dr. İrfan ERDOĞAN \\ İstanbul Üniversitesi-Cerrahpaşa, Hasan Âli Yücel Eğitim Fakültesi, Eğitim Bilimleri Bölümü, \\ İstanbul / Türkiye, irfanerdogan@iuc.edu.tr, ORCID: 0000-0003-4535-4956
}

\begin{abstract}
The aim of this study is to investigate the relationship between peer bullying tendency and cyberbullying tendency and peer bullying victimization and cyberbullying victimization among middle school students. The study was carried out with 1080 middle school students (551 girls and 529 boys) in Istanbul. Demographic Information Form, Peer Bullying Tendency Scale, Peer Bullying Victimization Scale, Cyberbullying Tendency Scale and Cyber Victimization Scale were administered to the students. The data obtained were analyzed with Pearson Product Moment Correlation, independent sample t-test and one-way analysis of variance. Results of the study indicated a significant relationship between peer bullying tendency and cyberbullying tendency of students. In addition, another significant relationship was found between the students' exposure to peer bullying and cyberbullying. In addition to these, results of the study revealed a significant relationship between students' tendency to peer bullying and their exposure to cyberbullying and again a significant relationship between students'
\end{abstract}

\footnotetext{
${ }^{1}$ This study was submitted as Master's Thesis to Istanbul University, Educational Sciences Institute. 
exposure to peer bullying and cyberbullying. The recommendations for future research and for stakeholders-school counselor, teachers, parents and adolescents- are presented.

Keywords: Peer bullying; Peer bullying victimization; Cyberbullying; Cyberbullying victimization.

\title{
Ortaokul Öğrencilerinde Akran Zorbalığg ile Siber Zorbalık Arasındaki İlişkinin İncelenmesi
}

\begin{abstract}
$\ddot{O} z$
$\mathrm{Bu}$ çalışmanın amacı ortaokul öğrencilerinde akran zorbalığı eğilimi ve mağduriyeti ile siber zorbalık eğilimi ve mağduriyeti arasındaki ilişkilerin incelenmesidir. Araştırmaya İstanbul'da ortaokula devam eden 551 kız öğrenci, 529 erkek öğrenci katılmıştır. Katılımcılara demografik bilgi formu, Akran Zorbalığı Eğilimi Ölçeği, Akran Zorbalığı Mağdurları Belirleme Ölçeği, Siber Zorbalık Eğilimi Ölçeği ve Siber Mağduriyet Ölçeği uygulanmıştır. Araştırmada elde edilen veriler Pearson Momentler Çarpımı Korelayonu, bağımsız gruplar t testi ve tek yönlü varyans analizi ile incelenmiştir. Araştırma sonucunda, akran zorbalığ eğilimi ile siber zorbalık eğilimi arasında ve akran zorbalığı mağduriyeti ile siber zorbalık mağduriyeti arasında anlamlı ilişkiler bulunmuştur. Ayrıca, akran zorbalığı eğilimi ile siber mağduriyet arasında ve akran zorbalığı mağduriyeti ile siber zorbalık arasında da anlamlı ilişkiler olduğu görülmüştür. Araştırma bulguları tartışılarak bilimsel araştırmalar için öneriler sunulmuştur. Bununla birlikte okul psikolojik danışmanları, öğretmenler, ebeveynler ve öğrenciler için öneriler sunulmuştur.
\end{abstract}

Anahtar Kelimeler: Akran zorbalığı; Akran zorbalığı mağduriyeti; Siber zorbalık; Siber zorbalık mağduriyeti.

\section{Introduction}

Peer bullying is one of the most important problems that are frequently encountered at schools and tend to increase continuously. Peer bullying which is considered as a sub-dimension of aggression in the literature is also explained by concepts such as traditional bullying, traditional peer bullying, or school bullying (Cowie and Jennifer, 2008; Monks and Smith, 2006; Olweus, 1993; Rivers and Smith, 1994). Along with the problem that students engage in violent behaviors towards each other and those around them physically and verbally, there are different dimensions of the problem occurring in different ways within the scope of peer bullying. Peer bullying not only damages the 
safe school climate but also brings about many serious problems in school environments. As a matter of fact, it is not possible that students benefit from educational activities efficiently in school buildings, where security need, one of the most basic needs of people, is not provided (Ögülmüş, 2006). In this regard, the students who are exposed to bullying may be adversely affected from academic, social and personal dimensions. Bullying causes students to perceive schools as insecure places (Farrington, 1993).

Peer bullying has been defined from different perspectives and many definitions have been made to identify those who exhibit bullying behaviors and are exposed to these behaviors (Arora, 1996; Besag, 1995; Olweus 1993). The most prominent elements commonly referred to among these definitions are persistent and repetitive peer bullying, imbalance of power between the parties, and deliberate detrimental behavior that occurs verbally, physically and psychologically (Olweus, 1993). Even, peer bullying is divided into various categories as patterns of behavior. The conceptualization of these categories depends on bullying and direct-indirect bullying involving verbal, physical or relational attitudes and behaviors (Besag, 1995; Rigby, 2007).

With the increasing prevalence of peer bullying in schools, the number of studies on this issue has increased rapidly and, various intervention programs have been developed and solutions to the problem have been produced (Dölek, 2002; Merrell, Gueldner, Ross and Isava, 2008; Türktan, 2013). Despite these solution proposals and intervention programs, peer bullying at schools continues with many types such as physical, verbal, emotional, behavioral, disruptive, sexual, racist, hiding and taking something that belongs to someone else (Koç, 2006). As a result of technological developments and that communication and interaction has been brought to a virtual environment, peer bullying behaviors have gained a different composition.

While the supply of digital technologies has increased, the use of these technologies has become an inevitable phenomenon of our time. As a matter of fact, in all areas of life, the use of tools such as computers, mobile phones and tablets in workplaces, hospitals, shopping malls, schools, homes and even on the streets is now perceived as a normal situation. Furthermore, inadequate use of technology can lead to a major shortage of lagging behind life. The importance of being literate in the past has converted to a different form with digital technology today. The current counterpart of the perception of literacy is technology literacy, which begins with computer and internet familiarity. 
This is especially important in order to provide the best benefit from the use of digital technologies and to prevent potential hazards (Erdoğan, 2011).

With the widespread use of internet-based communication among children and young people, the way to bring bullying behaviors of students into a virtual environment has been opened. The transition of bullying from physical to virtual environment and continuing in virtual environment raises the problem defined as "cyberbullying" (Aricak et al., 2008; Belsey, 2006; Patchin and Hinduja, 2006; Willard, 2007; Yaman, Eroğlu and Peker, 2011). Cyberbullying is defined as intentional, repetitive and hostile behavior displayed by an individual or group to harm others by using information and communication technologies. It could be observed in e-mails, mobile phone messages, instant messages, chat rooms, social networks, personal blog pages, survey sites and with other digital technology tools (Arıcak, 2009; Beale and Hall, 2007; Belsey, 2006; Strom and Strom, 2005; Tim and Perez, 2010). It is possible for students who communicate and interact by using internet and mobile phones to reach others easily by hiding their identity in a virtual environment. While providing a safe space for cyberbullies who can perform with anonymous identity, virtual environments do not provide protection for the victims to avoid from these behaviors (Patchin and Hinduja, 2007).

Although cyberbullying is considered as a kind of peer bullying in a virtual environment, it differs from peer bullying in some aspects. These differences could be listed as usage of the internet and other digital technologies and requirement of competence in such technologies, ability to conceal the identity, the rapid spread of negativity encountered in the virtual environment and reaching a large audience, inadequate family supervision, children's and young people's concerns about getting help from adults (Ayas and Horzum, 2012; Belsey, 2006; Law, Shapka, Hymel, Olson and Waterhouse, 2011; Shariff, 2005). While cyberbullying has some different characteristics than peer bullying mentioned above, the power imbalance in the behaviors emerging as the result of these two tendencies and the repetitive and damaging aspects of behaviors are similar for both types of bullying. Like peer bullying, cyberbullying has a negative effect on development, social relations and academic success of children and adolescents (Haynie et al., 2001; Juvonen, Graham and Schuster, 2003; Nansel et al., 2001).

When the studies on peer bullying and cyberbullying are examined, it is stated that peer bullying happening verbally negatively affects the self- 
perception of both females and males (Anderson, 2007), it is also found that the self-esteem of people exposed to bullying is lower (Keskin, 2010). In addition to this, it is stated that bullying also changes students' perception of school climate. Students perceive the school as a life space and it is stated that the meaning attributed to the school has a relationship with witnessing bullying experiences (Arıman, 2007). In a study examining peer bullying and psychological symptoms of ninth grade students, it was determined that most of the students were in bully / victim group and it is followed by the students in the non-interfering, victim and bully group, respectively. Students who do not engage in peer bullying experience less anxiety, depression and negative selfesteem compared to the victim and bully / victim students (Acar, 2009). Studies on cyberbullying in the 2000s have increased and become widespread as mentioned before. The impact areas of cyberbullying, that students may be exposed to at anytime and anywhere in the digital age, have been examined and evaluated. In line with the findings of many studies in the literature, it has been concluded that male students apply cyberbullying more and are exposed to cyberbullying more than female students (Burnukara, 2009; Campfield, 2006; Çifçi, 2010; Lightburn, 2009; Topçu, 2008). Along with gender differences, cyberbullying experiences are discussed with various variables. In the study of O'Harra (2012) on the roles and responsibilities of school counselors related to students' cyberbullying experiences, school counselors evaluated that students' cyberbullying experiences are more critical than their peer bullying experiences and that they were insufficient in intervention. Ubertini (2010) stated that students exposed to cyberbullying experience high levels of depression and low self-esteem. In addition, students' attempting to cyber bullying decreases when life satisfaction and social support increase. Secondary school students exposed to peer bullying and cyberbullying were found to have higher levels of anxiety and depression than those who display peer bullying and cyberbullying behavior (Chin, 2011; Johnson, 2011). Victims of both types of bullying reported that they have problems that affect their psychological health negatively, such as anxiety and depression. In addition to those, it has been determined that students exposed to cyberbullying tend to move away from school, their academic success decreases, they experience intense loneliness and are excluded from the group of friends (Johnson, 2011). Besides, it may be possible for them to transfer the school violence to out-ofschool areas through cyber bullying and reach to wider masses on the internet (Trachtenbroit, 2011). 


\section{Significance of the Study}

As stated that the peer bullying experiences that students display and experience in social environments continue in the virtual environments, peer bullying and cyber bullying are the continuation of each other, in other words (Hines, 2011). Also, they are separate phenomena, but in terms of the negative social and psychological conditions, they show similar characteristics (Brown, 2011). That students who tend to bully at school continue this tendency in cyber context and the victimization of students who are bullied in the school continue in the cyber environment is thought to take place in a linear way. On the other hand, that those who tend to bully in school are exposed to bullying in cyber space and those who are exposed to bullying at school attempt to bully in the cyber context indicates the cyclicality to be considered. As a matter of fact, the tendency to display bullying behavior and exposure to bullying in this relational context can be intertwined in both face to face communication and cyber communication. This situation brings with it the difficulty of determining the limits of bullying attitudes and behaviors. It is necessary to evaluate the experiences of bullying, that of bullying itself and exposure to it, in a holistic way and from a triple framework-bully, victim and bully-victim. In this study, it is aimed to examine to what extent peer bullying and cyberbullying tendency and victimization are related.

\section{Purpose of the Study}

The main purpose of this study was to examine whether students who show tendency to peer bullying involve in bullying behaviors outside the school environment, i.e, in a virtual context, and whether peer bullying victimization continue in the cyber environment within a holistic way of evaluation. Therefore, in this study, the relationship between peer bullying tendency and victimization and cyberbullying tendency and victimization of cyberbullying among middle school students are examined.

The research questions that are expected to be answered for these purposes are as follows:

1. What is the level of peer bullying tendency and victimization of students?

2. What is the level of cyberbullying tendency and victimization of cyberbullying of students?

3. Is there a significant relationship between students' tendency to peer bullying and cyberbullying? 
a. Is there a significant relationship between sub-dimensions of peer bullying tendency which are negative reflections, lack of emotional sharing, self-justification, making others upset, use of force to others, remain insensitive and the tendency of cyberbullying?

4. Is there a significant relationship between students' tendency to peer bullying and victimization of cyberbullying?

a. Is there a significant relationship between sub-dimensions of peer bullying tendency which are negative reflections, lack of emotional sharing, self-justification, making others upset, use of force to others and remain insensitive and victimization of cyberbullying?

5. Is there a significant relationship between students' victimization of peer bullying and cyberbullying tendency?

a. Is there a significant relationship between cyberbullying tendency and peer bullying sub-dimensions of peer bullying which are scare/intimidation, mockery, open attack, relational attack and harm to personal belongings?

6. Is there a significant relationship between students' victimization of peer bullying and cyberbullying?

a. Is there a significant relationship between victimization of cyberbullying and victimization of peer bullying sub-dimensions which are intimidation, intimidation, mocking, open attack, relational attack and harm to personal belongings?

\section{Method}

\section{Research Design}

In this study, the relationships between variables -peer bullying tendency and victimization and cyberbullying tendency and victimization of cyberbullying- were examined. Therefore, this study was designed by relational research design which is one kind of quantitative research. In relational studies, it is aimed to determine and observe the quantity and direction of relationships between variables (Fraenkel, Wallen and Hyun, 2010).

\section{Participants}

It is important that participants should be selected with equal gender representation among the ones who are between 11 and 15 yeas and estimated to be peer and cyber-bullied so a total of 1080 students [529 males (49\%) and 551 females $(51 \%)]$ participated in this study. $13.9 \%(\mathrm{n}=150)$ of the sample 
was fifth, 32.8\% $(\mathrm{n}=354)$ was sixth, $26 \%(\mathrm{n}=281)$ was seventh, $27.3 \%(\mathrm{n}=295)$ was eighth graders. In addition, the ages of the participants ranged between $11-15$ and mean of age was $12.78(\mathrm{SD}=1.11)$.

\section{Instruments}

\section{Demographic Information Form}

Demographic Information Form composed by the researchers was used to obtain demographic data about the participants. In Demographic Information Form, there are questions about students' gender, age, class level, parents' education level, monthly income status of their families, having computers connected to the internet at home, places they connected to the internet, tools connected to the internet, and daily average internet usage periods. The form does not contain any questions that could reveal identity of participants in accordance with Scientific Ethics and in order to get realistic answers from the students.

\section{Peer Bullying Tendency Scale (PBTS)}

Validity and reliability studies of Peer Bullying Tendency Scale, which is developed by Dölek (2002) were conducted in a sample of 440 students, 252 of whom were female and 188 of whom were male. The construct validity of the scale was examined by exploratory factor analysis (Varimax Rotation) and it was found that the scale had a six-factor structure. The scale items require replies including four options which are Never Agree-Disagree-AgreeStrongly Agree. For the reliability analysis of the scale, lower and upper quarters, item analysis and test-retest analyses were used. The independent samples $t$ test between the lower and upper quarters showed that the items in the dimensions were significantly differentiated from the total of the scale. Also, test-retest continuity coefficient was calculated. The scale was applied to 24 students at 2-week intervals and the relationships between two applications were calculated with Pearson correlation coefficient for the dimensions of the scale. Coefficients were found respectively; .47 for the total of the scale; .41 for negative reflection sub-dimension; 69 for the self-justification sub-dimension and .55 for remain insensitive sub-dimension.

\section{Peer Bullying Victimization Scale (PBVS)}

The items of this scale adopted by Gültekin and Say1l (2005) confirmed five factors as a result of the Promax Rotation factor analysis conducted in the context of the principal component analysis. These factors were named as "intimidation, open attack, mockery, relational attack, and harm to personal 
belongings". For the reliability studies of the scale, Cronbach Alpha internal consistency coefficients were calculated for each factor. The Cronbach Alpha internal consistency coefficient of the whole scale was $.86, .73$ for the intimidation factor, .72 for the open attack factor, .68 for the mockery factor, .72 for the relational attack factor, and .67 for the harm to personal belongings. Criterion validity was examined to determine whether the scores obtained from the scale differentiate the exposure to peer bullying according to the students' reports. As a conclusion, it is decided that this scale is valid and reliable.

\section{Cyberbullying Tendency Scale (CBTS)}

Cyberbullying Tendency Scale developed by the researchers consists of 17 items. The scale was developed on a five-point Likert scale to measure the tendency of cyberbullying including "Never - Rarely - Sometimes - Mostly Always" response options. Exploratory factor analysis was used to test the construct validity of the scale. Cronbach's Alpha analysis were used to calculate the internal consistency coefficient and Pearson correlation technique was used to find the item-total correlation and test-retest reliability coefficient. The upper and lower $27 \%$ means of the scale were compared with $t$ test.

\section{Content validity}

During the development of the scale, the related literature was examined in order to determine the cyberbullying attitudes and behaviors that the students encountered and items containing the tendency of cyberbullying were formed in line with the data obtained from the literature. A total of 54 items in the item pool were evaluated by academics and experts from the fields of Educational Sciences, Psychology, Guidance and Psychological Counseling and Turkish Language and Literature. Based on the opinions of academics and experts, items with the same or similar meaning were eliminated; necessary corrections were made to make sure that the expressions were clear and understandable. At the final stage, it was decided that the scale would consist of a total of 17 items. This form was applied to 264 secondary school students.

\section{Construct validity}

In order to test the construct validity of the scale, exploratory factor analysis technique was used in the context of principal component analysis. Before the exploratory factor analysis, sampling suitability and Barlett Sphericity tests were run. In order for the data to be suitable for factor analysis, KMO is higher than .60 and Barlett Test should be significant (Büyüköztürk, 2011). KMO sampling coefficient of the scale was .880 and Barlett Sphericity 
test $\chi^{2}$ value was found to be $2164.28(p<.00)$. When the component matrix of the scale was examined, it was observed that all items were loaded under the first factor. This single factor explained $41.46 \%$ of the total variance. At the same time, the breaking point on the scree plot was examined and the scale showed a single-factor structure from the breaking point. Factor loads under a single factor range from .50 to .81 .

\section{Reliability}

Reliability of the scale was calculated with internal consistency reliability (Cronbach Alpha) and test-retest methods. Cronbach Alpha internal consistency coefficient for the whole scale was found to be .90 . The internal consistency reliability coefficient obtained with split-half method was calculated as .91 . Besides, in order to determine the reliability coefficient by testretest method, the scale items were re-applied to the first group after four weeks. The test-retest reliability coefficient of the scale at the end of the second application was found to be .66 .

\section{Item analysis}

The item-total correlations of the Cyberbullying Tendency Scale were compared with the item scores of the lower $27 \%$ and upper $27 \%$ groups. For all items in the scale, item-total correlations ranged from .45 to .73 and t-values were significant $(p<.001)$. This shows that the scale has a distinctive feature. Based on the validity analysis, it can be concluded that the items of the scale have a high validity and they measure the same attitudes and behaviors.

After all, it was decided that Cyberbullying Tendency Scale could be used as a valid and reliable measurement tool based on results of exploratory factor analysis for the construct validity, psychometric findings obtained from Cronbach's Alpha, split-half method, test-retest reliability and item discrimination analyzes.

\section{Cyber Victimization Scale (CVS)}

The construct validity of the scale developed by Arıcak, Tanrikulu and Kınay (2012) was examined by exploratory factor analysis and it was observed that the scale had a single-factor structure. The Kaiser-Meyer-Olkin sample suitability value was .882 and the Bartlett Sphericity Test Chi-Square value was $4374.93(p<.05)$. At the same time, when the breakpoint on the scree plot is examined, it is seen that the scale has a single-factor structure. This single factor explained $30.17 \%$ of the total variance. Factor loads of items under a single factor range from .43 to .67 . It is accepted that these load values 
are acceptable values for one factor. Cronbach's Alpha coefficient for the whole scale was .89 and the test-retest reliability coefficient was .75 ( $\mathrm{n}=96)$. The scale consists of 24 items and is answered on a dual (yes and no) scale. "No" is calculated for one point and "Yes" is calculated for two points. Thus, the lowest score that can be obtained from the scale is 24 and the highest score is 48 . High scores indicate the high level of cyber victimization.

\section{Data Analysis and Procedure}

Data collection tools were applied to 1080 students (559 females and 521 males) attending middle schools in various districts of Istanbul. Before application of the scales, necessary permissions were obtained from Istanbul Provincial Directorate of National Education. The researchers participated in all the applications in different schools and the students were informed about the research topic and the scale instructions were read.

In this study, SPSS 22 program was used for data analysis. Statistical techniques and tests appropriate to the dataset and research questions were used in the analysis of the data obtained from the scales. In addition to descriptive statistical analysis, Pearson Product-Moment Correlation Analysis, independent sample t-test and one-way ANOVA were used. In order to test the significant difference between the groups after ANOVA, Bonferroni multiple comparison test which is one of the Post Hoc Analysis was performed. In order to evaluate the results of the analyzes, $p=.05$ level was accepted as critical value.

\section{Findings}

First, participants' demographic variables were described and then differences of peer bullying, cyberbullying and both victimization types were addressed according to gender and grade level. Furthermore, based on research questions the relationships between peer bullying, cyberbullying and both type of victimizations were analyzed.

\section{Demographic Results}

In this study, $51 \%$ of the participants were female and $49 \%$ of them were male. Considered by grade level, $13.9 \%$ of participants attended $5^{\text {th }}$ grade, $32.8 \%$ of them attended $6^{\text {th }}$ grade, $26 \%$ of them attended $7^{\text {th }}$ grade and $27.3 \%$ of them attended $8^{\text {th }}$ grade. In addition to these, $71.3 \%$ of participants had computers connected to the Internet while the rest did not have. Besides $71.9 \%$ of participants connected to the Internet at home, $4.3 \%$ of them at school, $7.7 \%$ of them at cafés. The tool used mostly to connect to the Internet 
was a personal computer (PC). Participants also connected to the Internet by laptop (29.3\%), mobile phone (13.2\%) and tablets (6.5\%). The participants reported that the duration of daily activities on the Internet 0-2 hours a day. The demographic information of the participants was presented in Table 1.

Table 1. Demographic Information of Participants

\begin{tabular}{llccc}
\hline & & $\mathbf{n}$ & $\mathbf{\%}$ & Cumulative \% \\
\hline Participants & Female & 551 & 51 & 51 \\
& Male & 529 & 49 & 100 \\
\hline Grade level & $5^{\text {th }}$ & 150 & 13.9 & 13.9 \\
& $6^{\text {th }}$ & 354 & 32.8 & 46.7 \\
& $7^{\text {th }}$ & 281 & 26 & 72.7 \\
& $8^{\text {th }}$ & 295 & 27.3 & 100 \\
\hline Having computers & Yes & 770 & 71.3 & 71.3 \\
connected to Internet & No & 310 & 28.7 & 100 \\
\hline Places where & At home & 777 & 71.9 & 71.9 \\
connected to Internet & At school & 46 & 4.3 & 76.2 \\
& At cafe & 83 & 7.7 & 83.9 \\
& Other places & 174 & 16.1 & 100 \\
\hline Tools which connected & PC & 551 & 51.0 & 51.0 \\
to Internet & Laptop & 316 & 29.3 & 80.3 \\
& Mobile phone & 43 & 13.2 & 93.5 \\
& Tablet & 70 & 6.5 & 100 \\
\hline Duration of daily & None & 63 & 5.8 & 5.8 \\
activities on Internet & 0-2 hour & 684 & 63.4 & 69.2 \\
& 2-4 hour & 222 & 20.6 & 89.7 \\
& 4 + hour & 111 & 10.3 & 100 \\
\hline
\end{tabular}

\section{Students' Peer Bullying Tendency and Peer Bullying Victimization}

The mean score of peer bullying tendency of the students participating in the study was $46.31(\mathrm{SD}=12.07)$ and the mean score of peer bullying exposure was $10.20(\mathrm{SD}=10.98)$. Peer bullying tendency and peer bullying exposure percentages were determined based on the lowest cut-off point that can be obtained from the scales in which peer bullying tendency and victimization of peer bullying were examined. According to this, $30.8 \%(n=333)$ of the students have the tendency to peer bullying, while $80.1 \%(n=865)$ were exposed to peer bullying.

\section{Students' Cyberbullying Tendency and Cyberbullying Victimization}

The mean score of cyberbullying tendency of students was 20.33 $(\mathrm{SD}=7.15)$ and the mean score of cyberbullying was $26.74(\mathrm{SD}=4.25)$. Cyberbullying tendency and exposure to cyberbullying percentages of students were determined based on the lowest score that can be obtained from the scales in which cyberbullying tendency and cyberbullying were examined. 
Accordingly, $47.5 \%$ of students $(n=513)$ have the tendency to cyberbullying, while $54.8 \%(\mathrm{n}=592)$ were exposed to cyberbullying.

\section{The Difference Between Females and Males According to Peer Bul- lying Tendency and Peer Bullying Victimization}

The results of peer bullying and its victimization differences according to gender has shown in Table 2. There was a significantly differences between female and male students considering peer bullying tendency. Females' peer bullying tendency level was lower than male students $\left(t_{(1078)}=-7.83, p=.00\right)$. Similarly, females' victimization level of peer bullying was significantly lower than male students' victimization level $\left(t_{(1078)}=-2.41, p=.02\right)$.

Table 2. Results of Independent Samples $t$ Test for Peer Bullying and Victimization according to Gender Differences

\begin{tabular}{llccccccc}
\hline & & $\mathbf{n}$ & $\overline{\mathbf{X}}$ & SD & SEM & $\boldsymbol{t}$ & $\boldsymbol{d f}$ & $\boldsymbol{p}$ \\
\hline Peer Bullying & Female & 551 & 43.57 & 11.63 & .50 & -7.83 & 1078 & .00 \\
& Male & 529 & 49.17 & 11.87 & .52 & & & \\
\hline Victimization of & Female & 551 & 9.41 & 9.70 & .41 & -2.41 & 1078 & .02 \\
Peer Bullying & Male & 529 & 11.02 & 12.14 & .53 & & & \\
\hline
\end{tabular}

\section{The Difference Between Females and Males According to Cyber- bullying Tendency and Cyberbullying Victimization}

There were also significant differences between female and male students' cyberbullying tendency. The results were presented in Table 3.

Table 3. Results of Independent Sample $t$ Tests for Cyberbullying and Victimization according to Gender Differences

\begin{tabular}{lllllllll}
\hline & & $\mathbf{n}$ & $\overline{\mathbf{X}}$ & SD & SEM & $\boldsymbol{t}$ & $\boldsymbol{d} \boldsymbol{f}$ & $\boldsymbol{p}$ \\
\hline Cyberbullying & Female & 551 & 19.22 & 4.65 & .20 & -5.26 & 1078 & .00 \\
& Male & 529 & 21.48 & 8.90 & .39 & & & \\
\hline Victimization of & Female & 551 & 26.68 & 4.07 & .17 & -.48 & 1078 & .63 \\
Cyberbullying & Male & 529 & 26.80 & 4.44 & .19 & & & \\
\hline
\end{tabular}

Accordingly, male students' cyberbullying level was significantly higher than females. On the other hand, there was not any significant differences between females and males with regard to victimization of cyberbullying.

\section{The Difference Between Students' Grade Levels According to Peer Bullying Tendency and Peer Bullying Victimization}

As presented in Table 4, there was a significant difference between the tendency of peer bullying and victimization of peer bullying according to the grade level of the participants [respectively, $F_{(3.1076)}=3.28, \quad p=.02$; 
$\left.F_{(3.1076)}=4.16, p=.00\right]$. Bonferroni multiple comparison test was performed to test the significant difference in terms of the participants' grade levels. As can be seen in Table 4, while fifth-grade students tended to have significantly less peer bullying than sixth and eighth-grade students, sixth grade students were exposed to more peer bullying significantly than the other graders.

Table 4. Results of One-Way ANOVA for Peer Bullying and Victimization According To Students' Grade Level Differences

\begin{tabular}{lllllllll}
\hline & & $\mathbf{n}$ & $\overline{\mathbf{X}}$ & SD & SEM & $\boldsymbol{F}$ & $\boldsymbol{d f}$ & $\boldsymbol{p}$ \\
\hline Peer Bullying & $5^{\text {th }}$ & 150 & 43.71 & 12.55 & 1.02 & 3.28 & 1079 & .02 \\
& $6^{\text {th }}$ & 384 & 46.86 & 12.51 & .67 & & & \\
& $7^{\text {th }}$ & 281 & 45.99 & 11.44 & .68 & & & \\
& $8^{\text {th }}$ & 295 & 47.28 & 11.72 & .68 & & & \\
& Total & 1080 & 46.31 & 12.07 & .37 & & & .00 \\
Victimization of & $5^{\text {th }}$ & 150 & 9.03 & 11.08 & .91 & 4.16 & 1079 & .00 \\
Peer & $6^{\text {th }}$ & 384 & 11.87 & 12.33 & .66 & & & \\
Bullying & $7^{\text {th }}$ & 281 & 9.52 & 10.47 & .62 & & & \\
& $8^{\text {th }}$ & 295 & 9.43 & 9.41 & .55 & & & \\
& Total & 1080 & 10.20 & 10.98 & .33 & & & \\
\hline
\end{tabular}

The Difference Between Students' Grade Level according to Cyberbullying Tendency and Cyberbullying Victimization

Table 5. Results of One-Way ANOVA for Cyberbullying and Victimization According to Students' Grade Level Differences

\begin{tabular}{lllllllll}
\hline & & $\mathbf{n}$ & $\overline{\mathbf{X}}$ & SD & SEM & $\boldsymbol{F}$ & $\boldsymbol{d f}$ & $\boldsymbol{p}$ \\
\hline Cyberbullying & $5^{\text {th }}$ & 150 & 19.29 & 5.30 & .43 & 3.86 & 1079 & .00 \\
& $6^{\text {th }}$ & 384 & 20.64 & 7.41 & .39 & & & \\
& $7^{\text {th }}$ & 281 & 19.56 & 4.47 & .27 & & & \\
& $8^{\text {th }}$ & 295 & 21.20 & 9.29 & .54 & & & \\
& Total & 1080 & 20.33 & 7.15 & .22 & & & \\
\hline Victimization of & $5^{\text {th }}$ & 150 & 25.67 & 3.68 & .30 & 4.83 & 1079 & .00 \\
Cyberbullying & $6^{\text {th }}$ & 384 & 26.71 & 3.96 & .21 & & & \\
& $7^{\text {th }}$ & 281 & 26.77 & 4.17 & .25 & & & \\
& $8^{\text {th }}$ & 295 & 27.28 & 4.82 & .28 & & & \\
& Total & 1080 & 26.74 & 4.25 & .13 & & & \\
\hline
\end{tabular}

As presented in Table 5, both cyberbullying tendency and cyberbullying victimization significantly differed according to the grade level of the students [respectively, $\left.F_{(3.1076)}=3.86, p=.009 ; F_{(3.1076)}=4.83, p=.002\right]$. As a result of the one-way ANOVA, Bonferroni multiple comparison test was used because of the significant difference in cyberbullying tendency and cyberbullying victimization between grade levels and the results were given in Table 5. According to this, it was found that the eighth-grade students had tendency to cyberbullying significantly more than the fifth and seventh grade students. 
Also, it was found that the students who were in the fifth grade were exposed to cyberbullying significantly less than the students who were in the sixth, seventh and eighth grade.

\section{Relationships Between Peer Bullying Tendency, Cyberbullying Tendency, Victimization of Peer Bullying and Victimization of Cyberbullying}

In this part, peer bullying tendency and cyberbullying tendency, victimization of peer bullying, victimization of cyberbullying, and relationships between the sub-dimensions of the tendency of peer bullying, sub-dimensions of peer bullying victimization, tendency of cyberbullying and its victimization were examined. The findings obtained were presented below.

Table 6. The Relationship Between Participants' Peer Bullying Tendency, Cyberbullying Tendency, Victimization of Peer Bullying and Victimization of Cyberbullying

\begin{tabular}{lccc}
\hline & Peer Bullying & $\begin{array}{c}\text { Victimization of Peer } \\
\text { Tendency }\end{array}$ & .23 \\
\hline Cyberbullying
\end{tabular}

There was a moderate significant positive correlation between students' peer bullying tendency and cyberbullying tendency $(r=.45, p=.00)$. Accordingly, as the tendency of peer bullying increases, so does the tendency of cyberbullying (Table 6). Findings of relationships between peer bullying victimization and cyberbullying victimization of students were presented in Table 6 . There was a moderate positive correlation between students' victimization of peer bullying and cyberbullying $(r=.32, p=.00)$. As peer bullying victimization increases, so does cyberbullying victimization. There was a low positive significant correlation between students' exposure to peer bullying and cyberbullying tendency $(r=.23, p=.00)$. Based on this finding, students who are exposed to peer bullying may tend to cyberbullying. Also, correlations between peer bullying tendency and cyberbullying victimization were examined. There was a low positive correlation between students' tendency to peer bullying and their exposure to cyberbullying $(r=.28, p=.00)$. As students' tendency to peer bullying increases, their exposure to cyberbullying increases. 
Table 7. The Relationship Between Participants' Cyberbullying Tendency, Victimization of Cyberbullying and Sub-Dimensions Peer Bullying Tendency

\begin{tabular}{llllllll}
\hline & & NR & LES & SJ & UO & FO & RI \\
\hline Cyberbullying & $\mathrm{r}$ & .32 & .15 & .20 & .43 & .42 & .09 \\
Tendency & $\mathrm{p}$ & .00 & .00 & .00 & .00 & .00 & .00 \\
\hline Victimization of & $\mathrm{r}$ & .21 & .08 & .17 & .25 & .25 & .03 \\
Cyberbullying & $\mathrm{p}$ & .00 & .00 & .00 & .00 & .00 & .27 \\
& $\mathrm{~N}$ & 1080 & 1080 & 1080 & 1080 & 1080 & 1080 \\
\hline
\end{tabular}

Note. NR: Negative reflection, LES: lack of emotional sharing, SJ: self-justification, UO: to upset others, FO: to force to others, RI: remain insensitive.

Relationships between sub-dimensions of peer bullying tendency and cyberbullying tendency and victimization of cyberbullying were examined (Table 7). There were significant correlations between students' cyberbullying tendency and sub-dimensions of peer bullying, negative reflection $(r=.32$, $p=.00)$, lack of emotional sharing $(r=.15, p=.00)$, self-justification $(r=.20$, $p=.00)$, to upset others $(r=.43, p=.00)$, to force to others $(r=.42, p=.00)$, remain insensitive $(r=.09, p=.00)$. There were significant correlations between students' exposure to cyberbullying and sub-dimensions of peer bullying exposure, negative reflection $(r=.21, p=.00)$, lack of emotional sharing $(r=.08$, $p=.00)$, self-justification $(r=.17, p=.00)$, to upset others $(r=.25, p=.00)$, to force to others $(r=.25, p=.00)$. There was no significant relationship between remain insensitive sub-dimension of peer bullying tendency and being exposed to cyberbullying $(r=.03, p=.27)$.

Table 8. The Relationship Between Participants' Cyberbullying Tendency, Victimization of Cyberbullying and Sub-Dimensions of Peer Bullying Victimization

\begin{tabular}{lllllll}
\hline & & IN & MO & OA & RA & DPB \\
\hline Cyberbullying Tendency & $\mathrm{r}$ & .27 & .16 & .15 & .19 & .18 \\
& $\mathrm{p}$ & .00 & .00 & .00 & .00 & .00 \\
\hline Victimization of Cyberbullying & $\mathrm{r}$ & .28 & .24 & .21 & .30 & .28 \\
& $\mathrm{p}$ & .00 & .00 & .00 & .00 & .00 \\
& $\mathrm{~N}$ & 1080 & 1080 & 1080 & 1080 & 1080 \\
\hline
\end{tabular}

Note. IN: intimidation, $M O$ : mock, OA: open attack, RA: relational attack, DPB: damage to personal belongings.

Relationship between sub-dimensions of peer bullying victimization and cyberbullying victimization were also examined. There were positive significant relationships between exposure to cyberbullying and sub-dimensions of exposure to peer bullying, intimidation $(r=.28, p=.00)$, mock $(r=.24$, $p=.00)$, open attack $(r=.21, p=.00)$, relational attack $(r=.30, p=.00)$ and 
damage to personal belongings $(r=.28, p=.00)$. Analyzes on the relationships between the sub-dimensions of exposure to peer bullying and cyberbullying tendency showed that there was a positive correlation between cyberbullying tendency and sub-dimensions of exposure to peer bullying, intimidation, mocking, open attack, relational attack and damage to personal belongings (respectively, $r=.27, p=.00 ; r=.16, p=.00 ; r=.15, p=.00 ; r=.19, p=.00 ; r=.18$, $p=.00)$.

\section{Discussion}

This section discusses and interprets findings on peer bullying tendency and peer bullying victimization and cyberbullying tendency and cyberbullying victimization. The relationships between these variables are examined and discussed one by one and their reflections are compared with the findings of the other studies. It is also important to note that peer bullying attitudes and behaviors is defined as "tendency" by integrating students' intentional, continuous and damaging attitudes and behaviors. Likewise, cyberbullying attitudes and behaviors are also expressed as "tendency".

Peer bullying has been an important and widespread problem that students have experienced in schools since the 1970s (Olweus, 1993). In recent years, with the increase in the use of digital technology, bullying experiences have been transferred to the virtual environment and has become a problem conceptualized as cyberbullying by researchers (Belsey, 2006). While frequency of peer bullying behaviors among students varies between $10 \%$ and $40 \%$, frequency of exposure to peer bullying varies between $5 \%$ and $45 \%$ (Giovazolias, Kourkoutas, Mitsopoulou and Georgiadi, 2010; Rech, Halpren, Tedesco and Santos, 2013; Spriggs, Iannotti, Nansel and Haynie, 2007). In studies which explore prevalence of cyberbullying, it is seen that while prevalence of cyberbullying behaviors ranged between $3 \%$ and $30 \%$, exposure to cyberbullying ranged between $10 \%$ and $35 \%$ (Arıcak et al., 2008; Englander, 2012; Li, 2006; Serin, 2012; Williams and Guerra, 2007). On the other hand, according to the findings obtained from this study, 30.8\% of the students had tendency to peer bullying and $80.1 \%$ reported that they were exposed to peer bullying. However, $47.5 \%$ of the students stated that they tend to cyberbullying and $54.8 \%$ stated that they were exposed to cyberbullying. These findings indicate that bullying in both types and situations (tendency and exposure) is quite common among middle school students whether it is recorded or observed by teachers or school administrators. As other studies also exhibit that 
bullying is happening with an increasing trend, it is crucial to take precautions. When that presenting bullying attitudes and behaviors and exposure to these situations can affect the whole school is taken into consideration, students who are not involved in bullying experiences witness this problem and may be affected by the environmental conditions.

When discussing the findings obtained in the study, another issue to be considered is whether gender is in a distinctive position about peer bullying or cyberbullying tendency and the cases of victimization related to them. When peer bullying tendency and peer bullying exposure are evaluated in terms of gender, male students show more peer bullying attitudes and behaviors than female students. It is also observed that male students are more often exposed to peer bullying than female students. (Espelage, Green and Polanin, 2011; Karaman, Kepenekçi and Çınkır, 2006; Liang, Flisher and Lombard, 2007). Similar to the findings in the literature, the findings of this study show that male students tend to attempt and are exposed to peer bullying more than female students, which is consistent with the findings of the studies (Besag, 1995; Burnukara, 2009; Olweus, 1996) focusing on gender variable. When students' cyberbullying tendency and cyberbullying exposure were analyzed in terms of gender, it is seen that male students have more cyberbullying tendency and attempt to cyberbullying behaviors more than female students. Various studies on cyberbullying have reached the conclusion that males display more cyberbullying behaviors than females and are exposed to those behaviors (Aricak et al., 2008; Erdur-Baker, 2010; Griezel et al., 2012; Li, 2006; Wade and Beran, 2011; Wang, Iannotti and Nansel, 2010; Y1lmaz, 2011). The findings of this study reveal that male students are tend to cyberbullying and to be cyberbullied more than female students. However, in some studies, it is observed that exposure to cyberbullying does not differ according to gender (Hinduja and Patchin, 2008; Law et al., 2011). Besides, in some studies, it was concluded that cyberbullying attitudes and behaviors and exposure to cyberbullying do not differ by gender (Hemphill et al., 2011).

When the types of peer bullying are examined in different phenomena such as physical, verbal, relational, direct and indirect ways, it is observed that some students interact with negative and damaging behaviors considered as bullying (Rigby, 2007; Wang, Iannotti and Nansel, 2010). From this damaging and sustained interaction, it is understood that peer bullying is not happening only in the school building; it is happening in the school garden, where 
students are all together, on the school way, at streets, at parks and in various areas (Harris and Petrie, 2003). From this point of view, peer bullying is considered only as a school bullying, which leads to a lack of conceptualization of the problem. When virtual environments are perceived as new social interaction zones and learning areas and the relationship between peer bullying and cyberbullying found in this study, it could be inferred that cyber bullying is transformed form of peer bullying. Also, that there is a relationship between peer bullying tendency and cyberbullying tendency supports the idea that certain number of participants who exhibit peer bullying tendency also exhibit cyberbullying tendency. The products of the innovation movements in digital technology are too fast to follow and they are placed in daily lives at a critical level. The use of information and communication tools has become widespread over time, and even preschool children have begun to use these tools to some extent. All these developments in information and communication technology have become an important part of the lives of children and adolescents as well as adults and negative forms of communication and interaction of students in social and physical environments have been digitized. Peer bullying attitudes and behaviors, which have an important place among the negative forms of communication and interaction of school age children, have also found their place in cyber world (Erdur-Baker and Kavşut, 2007; Kowalski, Morgan and Limber, 2012), which is consistent to findings of this study.

Based on the fact that bullying tendency is carried to virtual context by using digital technology products, it is thought that significant relationships of tendency to peer bullying revealed in this study with cyberbullying tendency supports all these conclusions and interpretations. It is mentioned in the literature that cyberbullying is the formation of peer bullying in a virtual environment, a dimension carried from a social environment to a virtual context and continuation of it outside the school (Boulton, Hardcastle, Down, Fowles and Simmonds 2013; Erdur-Baker and Kavşut, 2007; Kowalski, Limber and Agatston, 2008; Mark and Ratliffe, 2011; Menesini, Calussi and Nocentini, 2012; Patchin and Hinduja, 2006; Tettegah, Betout and Taylor, 2006). As a result of this study, it is observed that peer bullying behaviors have potential to continue in cyber world. In this context, correlational findings obtained in the study can be interpreted as students' tendency to present cyberbullying attitudes and behaviors increases, peer bullying tendency increases.

In addition to peer bullying attitudes in general, negative reflection, to 
upset others and to force others are considered as indicators of peer bullying tendency and associated with verbal and relational bullying style of peer bullying, which are sub-dimensions of the scale. The persistent negative effects of bullying students' communication with each other over the internet and mobile phones harms verbal and relational interaction (Boulton et al., 2013; Rivers, Duncan and Besag, 2007). Especially, negative reflection of peer bullying tendencies, attempts to upset others for various reasons and desire to force others compose the basis for emergence of cyberbullying behaviors.

Another finding of the study indicates that students exposed to peer bullying in the school environment are at risk of being bullied in the virtual environment. In other words, students who cannot or do not react bullies at school, react them in the virtual environment. Considering characteristics of the students who are exposed to bullying, being physically weak, being insufficient at the point of self-defense, and internalizing bullying with repetitive behaviors as an acceptable situation, it is thought to have potential to cause the victimization that started in the school to continue outside the school. There are studies (Bostic and Brunt, 2011; Dempsey and Storch, 2009; McQuade, Colt and Meyer, 2009; Willard, 2007) which support that finding and point out that peer bullying and peer bullying victimization do not finish at home. In addition to being exposed to cyberbullying and being exposed to bullying not only in the school, its spreading rapidly and lack of a safe place to shelter pose greater risks for the victims (Cappadocia, 2008; Kowalski and Limber, 2007).

However, it is possible for students who tend to peer bullying to be exposed to cyber-bullying. While students tend to exhibit bullying attitudes and behaviors in their interaction and communication with their peers in the school environment, they can be exposed to these behaviors on the internet. In other words, students who are exposed to bullying at school can respond to those who present bullying behaviors in cyber environment through mobile phone and internet without any harm (Feldman, 2011; Holfeld and Grabe, 2012; Li, 2007). This situation, which is evaluated within the bully-victim cycle, has attracted attention because it is the result or continuation of each other. In this study, it is thought that the relationship between students' tendency to bullying in school environment and bullying in virtual environment explains this situation.

Lastly, exposure of students to peer bullying may bring about danger 
that they tend to exhibit cyberbullying situations and behaviors. The students who are exposed to peer bullying in the school can respond to their interlocutors on the internet and choose the way of protecting themselves in order to show their strength to others (Aoyama, Utsumi and Hasegawa 2010; Holfeld and Grabe, 2012; Li, 2007; Menesini, Calussi and Nocentini, 2012). The relationship here explains the situation that students who tend to peer bullying may be exposed cyber-bullying.

\section{Conclusion}

Conclusively, in this study, there are four significant relationships found: Peer bullying tendency and cyberbullying tendency, peer bullying tendency and cyberbullying victimization, cyberbullying tendency and peer bullying victimization, peer bullying victimization and cyberbullying victimization. Considering the relationships that this study revealed about peer bullying and cyberbullying, it is obvious that these phenomena cannot be explained with a simple causality. The relationship between these two phenomena is shaped by the change in the roles of bully and victim according to the context. The hypothesis of changeability of these roles suggests that the risk of being bully or victimized is likely for all students. Therefore, students who exhibit both victim, bully and bully-victim tendencies are trained for alternative positive interactions and ways of communication to relieve from these negative experiences.

\section{Limitations}

This study was conducted with only middle school students, so generalizability of the results is limited to middle school students. In other words, findings and implications could vary at different age groups and education levels. In addition, to observe causes and outcomes of bullying, longitudinal and state-across studies should be designed however this study focuses on certain aspects of bullying (relations between them and cyclicality among them).

\section{Recommendations}

Based on the results of the study, suggestions for further scientific research, teachers, psychological counselors, families and students are as follows:

Considering that peer bullying does not only occur in schools, but also in places outside the school, especially on the internet, harmful attitudes and behaviors are spreading rapidly and leaving permanent effects, large-scale or nation-wide studies should be carried out. 
The prevalence and application / exposure patterns of the cyberbullying experiences of the students should be investigated in more detail and the results of these experiences should be determined through individual interviews and qualitative studies. Intervention programs should be developed in a manner specific to the negative behavioral diversity after identifying the consecutive negative situations that may arise.

Teachers play an important role in detecting students' bullying experiences as incidents of physical bullying in the school draw more attention. Although teachers' interventions to physical bullying are sufficient, teachers may fail to recognize verbal and relational bullying. In order to prevent bullying, it is recommended that teachers form classroom and school rules together with students, that those who are exposed to bullying can share these experiences with them easily, and that school units where bullying incidents occur most frequently are under control.

It is considered that intervention programs in schools related to peer bullying and cyberbullying are not sufficient. In addition to the seminars on cyberbullying, necessary attempts should be made for that school guidance and psychological counseling services should be considered as a solution. The negative dimensions of cyberbullying and victimization experiences should be conveyed to the students through small and large group activities.

Preventive studies should be carried out in order to prevent from negative experiences related to bullying thanks to- school guidance programs. Intervention efforts should be included in these school guidance programs on understanding, confronting, experiencing, and how to deal with cyberbullying.

Psychological counselors can witness peer bullying experiences of students in person in schools. Considering that peer bullying tends to continue outside the school, they should approach this very carefully by taking into consideration that students can exhibit and be exposed to cyberbullying behaviors. To do this, psychological counselors should organize and follow up individual counseling and group counseling, consultation with parents and teachers, peer peacemaking, psycho-training and intervention studies.

Psychological counselors may conduct interviews with students who present and are exposed to cyberbullying through some counseling approaches. At this point, cognitive approaches (Reality Therapy and Rational- 
Emotional Behavioral Intervention Approaches) and short-term counseling approaches can be effective for both victims and bullying behaviors.

Children and young people need to be aware of situations that could pose a threat to the online environment in which cyberbullying occurs. To do this, students should have information about the applications that will enable secure internet use. Students should be advised not to share personal information related to any social networking sites, e-mail accounts, gaming website profiles, and e-school application passwords on the Internet.

Considering that information can be spread rapidly on the internet and may be in the hands of any person, users should be careful while sharing private information, pictures, texts and images. In such cases, families should monitor their children's online experiences and intervene constructively when it is necessary.

Any content on the Internet is never lost. A content that a person shares on the Internet can go out of control of that person and anyone can have the control within seconds. This should be explained to both parents and students as much as necessary and help should be sought at the point of implementation. Parents should use software on their home computers developed for safe internet use and to prevent harmful sites. In addition, computers in the home should be in a location which is seen and is used by everyone to monitor the child.

It should be taken into consideration that students who exhibit cyberbullying behaviors and who are exposed to these behaviors are afraid to share their experiences with their families and teachers. Students who hesitate to be restricted from the use of the Internet try to deal with this situation on their own. Teachers and especially parents should monitor children at this point. It is important that families take a reassuring and protective attitude towards getting information from their children.

\section{References}

Acar, T. (2009). Peer bullying and psychological symptoms among ninth grade students. Master's thesis. Retrieved from Council of Higher Education Thesis Center. (Thesis No. 258364)

Anderson, G. (2007). The impact of bullying in schools on the adolescent's sense of self. Unpublished master thesis, Faculty of Human Sciences, University of Pretoria.

Aoyama, I., Utsumi S. and Hasegawa, M. (2010). Cyberbullying in Japan. In Q. Li, D. Cross and P. K. Smith, (Eds.), Cyberbullying in the global playground: 
Research from international perspectives (183-202). Oxford: Wiley-Blackwell.

Arıcak, O. T. (2009). Psychiatric symptomatology as a predictor of cyberbullying among university students. Eğitim Araştırmalart-Eurasian Journal of Educational Research, 34, 167-184.

Arıcak, O. T., Tanrıkulu, T. and Kınay, H. (2012). Initial psychometric findings of cyber victimization scale. Mediterranean Journal of Educational Research, 2(11), 1-6.

Arıcak, T., Siyahhan, S., Uzunhasanoğlu, A., Sarıbeyoğlu, S., Çıplak, S., Yılmaz, N. and Memmedov, C. (2008). Cyberbullying among Turkish adolescents. $C y$ berPsychology \& Behavior, 11(3), 253-261.

Arıman, F. (2007). Researching the relationship between the school climate and the bullying tendency among the 7th and 8th grade students in primary schools. Master's thesis. Retrieved from Council of Higher Education Thesis Center. (Thesis No. 211335)

Arora, C. M. J. (1996). Defining bullying: Towards a clearer general understanding and more effective intervention strategies. School Psychology International, 17(4), 317-330.

Ayas, T. and Horzum, M. B. (2012). On being cyberbully and victim among primary school students. Elementary Education Online, 11(2), 369-380.

Beale, A. V. and Hall, K. R. (2007). Cyberbullying: What school administrators (and parents) can do? The Clearing House: A Journal of Educational Strategies, Issues and Ideas, 81(1), 8-12.

Belsey, B. (2006). Cyberbullying: An emerging threat to the "Always On" generation. Retrieved from www.cyberbullying.org.

Besag, V. (1995). Bullies and victims in schools. Philadelphia: Open University Press.

Bostic, J. Q. and Brunt, C. C. (2011). Cornered: An approach to school bullying and cyberbullying, and forensic implications. Child Adolescent Psychiatric Clinic, 20(3), 447-465.

Boulton, M. J., Hardcastle, K., Down, J., Fowles, J. and Simmonds, J. A. (2013). A comparison of preservice teachers' responses to cyber versus traditional bullying scenarios: Similarities and differences and implications for practice. Journal of Teacher Education, 65(2), 145-155.

Brown, C. F. (2011). Middle school cyber victimization: outcomes, grade and gender differences, and the overlap with traditional victimization. Doctoral dissertation. Available from ProQuest Dissertations database. (UMI No. 1506277)

Burnukara, P. (2009). A descriptive study on traditional and cyber bullying in early and middle adolescence. Master's thesis. Retrieved from Council of Higher Education Thesis Center. (Thesis No. 258361)

Büyüköztürk, Ş. (2011). Sosyal bilimler için SPSS veri analizi el kitabı (15. baskı). Ankara: Pegem Akademi.

Campfield, D. C. (2006). Cyber bullying and victimization: Psychosocial characteristics of bullies, victims, and bully/victims. Doctoral dissertation. https://scholarworks.umt.edu/etd/288

Cappadocia, M. C. (2008). Cyberbullying and cyber victimization: Prevalence, stability, risk and protective factors, and psychosocial problems. Unpublished master thesis, York University, Faculty of Graduate Studies. 
Chin, M. A. (2011). Prevalence, gender differences, and mental health problems associated with traditional and cyberbullying. Doctoral dissertation. Available from ProQuest Dissertations database. (UMI No. 1496158)

Cowie, H. and Jennifer, D. (2008). New perspectives on bullying. Berkshire: Open Universtiy Press, McGraw Hill.

Çifçi, S. (2010). The relationship between cyberbullying and empathetic inclination level of 9th grade students. Master's thesis. Retrieved from Council of Higher Education Thesis Center. (Thesis No. 264429)

Dempsey, A. G. and Storch, E. A. (2009). Differences between peer victimization in cyber and physical settings and associated psychosocial adjustment in early adolescence. Psychology in the Schools, 46(10), 962-972.

Dölek, N. (2002). Resarching bullying behavior of student and a model for a prevention program. Doctoral dissertation. Retrieved from Council of Higher Education Thesis Center. (Thesis No. 320413)

Englander, E. K. (2012). Spinning our wheels: Improving our ability to respond to bullying and cyberbullying. Child and Adolescent Psychiatric Clinics, 21(1), 43-55.

Erdoğan, İ. (2011). Milli eğitime dair (2. baskı). Ankara: Nobel.

Erdur-Baker, Ö. (2010). Cyberbullying and its correlation to traditional bullying, gender and frequent and risky usage of internet mediated communication tools. New Media and Society, 12(1), 109-125.

Erdur-Baker, Ö. and Kavşut, F. (2007). Cyberbullying: A new face of peer bullying. Eurasian Journal of Educational Research, 7(27), 31-42.

Espelage, D., Green, H. and Polanin, J. (2011). Willingness to intervene in bullying episodes among middle school students: Individual and peer-group influences. The Journal of Early Adolescence, 32(6), 776-801.

Farrington, D. P. (1993). Understanding and preventing bullying. In M. Tonry and N. Morris, (Eds.), Crime and justice: An annual review of research (381-458). Chicago: University of Chicago Press.

Feldman, M. A. (2011). Cyber-Bullying in high school: Associated individual and contextual factors of involvement. Doctoral dissertation. Retrieved from. https://scholarcommons.usf.edu/etd/ 3099

Fraenkel, J. R., Wallen, N. and Hyun, H. (2011). How to design and evaluate research in education. New York: Mc Graw Hill.

Giovazolias, T., Kourkoutas, E., Mitsopoulou, E. and Georgiadi, M. (2010). The relationship between perceived school climate and the prevalence of bullying behavior in Greek schools: Implications for preventive inclusive strategies. Procedia Social and Behavioral Sciences, 5, 2208-2215.

Griezel, L., Finger, L. R., Bodkin-Andrews, G. H., Craven, R. G. and Yeung, A. S. (2012). Uncovering the structure of and gender and developmental differences in cyberbullying. The Journal of Educational Research, 105(6), 442-455.

Gültekin, Z. and Sayıl, M. (2005). A study of the reliability and validity of the peer victimization scale. Turkish Psychological Articles, 8(15), 47-61.

Harris, S. and Petrie, G. F. (2003). Bullying: The bullies, the victims, the bystander. Oxford, UK: The Scarecrow Press.

Haynie, D. L., Nansel, T., Eitel, P., Davis Crump, A., Saylor, K., Yu, K. and Simmons-Morton, B. (2001). Bullies, victims, and bully/victims: Distinct groups 
of youth at risk. Journal of Early Adolescence, 21(1), 29-49.

Hemphill, S. A., Kotevski, A., Tollit, M., Smith, R., Herrenkohl, T. I., Toumbourou, J. W. and Catalano, R. (2011). Longitudinal predictors of cyber and traditional bullying perpetration in Australian secondary school students. Journal of Adolescent Health, 51(1), 59-65.

Hinduja, S. and Patchin, J. (2008). Cyberbullying: An exploratory analysis of factors related to offending and victimization. Deviant Behavior, 29(2), 129-156.

Hines, H. N. (2011). Traditional bullying and cyber-bullying: are the impacts on selfconcept the same. Master's thesis. https://libres.uncg.edu/ir/wcu/f/Hines2011.pdf

Holfeld, B. andGrabe, M. (2012). Middle school students' perceptions of and responses to cyberbullying. Journal of Educational Computing Research, 46(4), $395-413$.

Johnson, C. L. (2011). An examination of the primary and secondary effects of cyberbullying: development and testing of a cyber-bullying moderator/mediator model. Doctoral dissertation.

https://digitalcommons.wayne.edu/oa_dissertations/242

Juvonen, J., Graham, S. and Schuster, M. A. (2003). Bullying among young adolescents: The strong, the weak, and the troubled. Pediatrics, 112(6), 1231-1237.

Karaman Kepenekci, Y. and Çınkır, Ş. (2006). Bullying among Turkish high school students. Child Abuse \& Neglect, 30(2), 193-204.

Keskin, T. (2010). The relation between self-esteem and bullying at primary school. Master's thesis. Retrieved from Council of Higher Education Thesis Center. (Thesis No. 278793)

Koç, Z. (2006). Regresment of high school students' bullying level. Doctoral dissertation. Retrieved from Council of Higher Education Thesis Center. (Thesis No. 187265)

Kowalski, R. M. and Limber, S. P. (2007). Electronic bullying among middle school students. Journal of Adolescent Health, 41(6), 22-30.

Kowalski, R. M., Limber, S. P. and Agatston, P. W. (2008). Cyberbullying: Bullying in the digital age. West Sussex: John Wiley \& Sons.

Kowalski, R. M., Morgan, C. A. and Limber, S. P. (2012). Traditional bullying as a potential warning sign of cyberbullying. School Psychology International, 33(5), 505-519.

Law, D. M., Shapka, J. D., Hymel, S., Olson, B. F. and Waterhouse, T. (2011). The changing face of bullying: An empirical comparison between traditional and internet bullying and victimization. Computers in Human Behavior, 28(1), 226-232.

Li, Q. (2006). Cyberbullying in schools: A research of gender differences. School Psychology International, 27(2), 157-170.

Li, Q. (2007). New bottle but old wine: A research of cyberbullying in schools. Computers in Human Behavior, 23(4), 1777-1791.

Liang, H., Flisher, A. J. and Lombard, C. J. (2007). Bullying, violence, and risk behavior in South African school students. Child Abuse \& Neglect, 31(2), 161171.

Lightburn, M. (2009). Cyberbullying: A content analysis of existing literature. Master's thesis, Available from ProQuest Dissertations database. (UMI No. 
1466169).

Mark, L. and Ratliffe, K. T. (2011). Cyber worlds: New playgrounds for bullying. Computers in the Schools, 28(2), 92-116.

McQuade, S. C., Colt, J. P. and Meyer, N. B. (2009). Cyber bullying: Protecting kids and adults from online bullies. London: Praeger.

Menesini, E., Calussi, P. and Nocentini, A. (2012). Cyberbullying and traditional bullying: Unique, additive, and synergistic effects on psychological health symptoms. In Li, Q., Cross, D. and Smith, P. K. (Eds.), Cyberbullying in the Global Playground (245-262). West Sussex: Blackwell.

Merrell, K., Gueldner, B., Ross, S. and Isava, D. (2008). How effective are school bullying intervention programs? A meta-analysis of intervention research. School Psychology Quarterly, 23(1), 26-42.

Monks, C. P. and Smith, P. K. (2006). Definitions of bullying: Age differences in understanding of the term, and the role of experience. British Journal of Developmental Psychology, 24(4), 801-821.

Nansel, T., Overpeck, M., Pilla, R., Ruan, W., Simons-Morton, B. and Scheidt, P. (2001). Bullying behaviors among U.S. youth: Prevalence and association with psychosocial adjustment. Journal of the American Medical Association, 285(16), 2094-2100.

O'Harra, J. (2012). Middle school counselors' roles and responsibilities in cyberbullying. Doctoral dissertation. Available from ProQuest Dissertations database. (UMI No. 1510936)

Olweus, D. (1993). Bullying at school: What we know and what we can do. Cambridge: Blackwell.

Olweus, D. (1996). Bully/victim problems in school: Facts and intervention. European Journal of Psychology of Education, 12(4), 495-510.

Öğülmüş, S. (2006). Okullarda şiddet ve alınabilecek önlemler. Eğitime Bakış, 2(7), $16-24$.

Patchin, J. and Hinduja, S. (2006). Bullies move beyond the school yard: A preliminary look at cyberbullying. Youth Violence and Juvenile Justice, 4(2), 148169.

Patchin, J. and Hinduja, S. (2007). Offline consequences of online victimization: School violence and delinquency. Journal of School Violence, 6(3), 89-112.

Rech, R. R., Halpern, R., Tedesco, A. and Santos, D. F. (2013). Prevalence and characteristics of victims and perpetrators of bullying. Jornal de Pediatria, 89(2), 164-170.

Rigby, K. (2007). Bullying in schools and what to do about it. Victoria: Acer Press.

Rivers, I., Duncan, N. and Besag, V. (2007). Bullying: A handbookfor educators and parents. London: Praeger.

Rivers, I. and Smith, P. K. (1994). Types of bullying behavior and their correlates. Aggressive Behavior, 20(5), 359-368.

Serin, H. (2012). Cyber bullying and cyber victimization experiences of adolescents and the views of educators and managers related to these issues. Doctoral dissertation. Retrieved from Council of Higher Education Thesis Center. (Thesis No. 317225)

Shariff, S. (2005). Cyber-dilemmas in the new millennium: Balancing free expression and student safety in cyber-space. McGill Journal of Education, 40(3), 467- 
487.

Spriggs, A. L., Iannotti, R. J., Nansel, T. R. and Haynie, D. L. (2007). Adolescent bullying involvement and perceived family, peer and school relations: Commonalities and differences across race/ethnicity. Journal of Adolescent Health, 41(3), 283-293.

Strom, P. S. and Strom, R. D. (2005). Cyberbullying by adolescents: A preliminary assessment. The Educational Forum, 70(1), 21-36.

Tettegah, S.Y., Betout, D. and Renee Taylor, K. (2006). Cyber-Bullying and Schools in an Electronic Era. In Tettegah, S.Y. and Hunter, R.C., (Eds.), Technology and Education: Issues in Administration, Policy, and Applications in K12 Schools (Advances in Educational Administration, Vol. 8), (17-28). Bingley: Emerald Group Publishing Limited.

Tim, C. and Perez, R. (2010). Seven deadliest social network attacks. Massachusetts: Elsevier Inc.

Topçu, Ç. (2008). The relationship of cyberbullying to empathy, gender, traditional bullying, internet use and adult monitoring. Master's thesis. Retrieved from Council of Higher Education Thesis Center. (Thesis No. 227700)

Trachtenbroit, M. L. (2011). Cyberbullying, school violence, and youth suicide Doctoral dissertation. https://aquila.usm.edu/dissertations/411

Türktan, Ş. (2013). The effects of a peer support program for coping with bullying on secondary school (6.and 7. graders') students' skills to cope with bullying. Doctoral dissertation. Retrieved from Council of Higher Education Thesis Center. (Thesis No. 322034)

Ubertini, M. (2010). Cyberbullying may reduce adolescent's well-being: can life satisfaction and social support protect them. Doctoral dissertation. Available from ProQuest Dissertations database. (UMI No. 3431797)

Wade, A. and Beran, T. (2011). Cyberbullying: The new era of bullying. Canadian Journal of School Psychology, 26(1), 44-61.

Wang, J., Ianotti, R. J. and Nansel T. R. (2010). School bullying among adolescents in the United States: Physical, verbal, relational, and cyber. Journal of Adolescent Health, 45(4), 368-375.

Willard, N. (2007). Educator's guide to cyberbullying and cyberthreats. Center for safe and responsible use of the Internet, 1-10.

https://cdn.ymaws.com/www.safestates.org/resource/resmgr/imported/educatorsguide.pdf on October, 2013.

Williams, K. R. and Guerra, N. G. (2007). Prevalence and predictors of Internet bullying. Journal of Adolescent Health, 41(6), 14-21.

Yaman, E., Eroğlu, Y. and Peker, A. (2011). Başa çıkma stratejileriyle okul zorbalı̆̆ ve siber zorbalı. İstanbul: Kaknüs.

Y1lmaz, H. (2011). Cyberbullying in Turkish middle schools: An exploratory study. School Psychology International, 32(6), 645-654. 